\title{
A COMPARISON OF EDUCATIONAL MISMATCHES ACROSS EUROPE
}

\author{
Kateřina Maršíková, Václav Urbánek
}

\section{Introduction}

Mismatches in the labour market are a current topic of discussion for researchers, scientists, politicians and even the general public. The literature focuses both on educational and job mismatches. The aim of this paper is to compare the situation concerning educational mismatches as evidenced by European data. Labour market data in almost all developed countries shows that university graduates more easily find employment compared to less educated people. Their jobs are also more qualified, more interesting and better paid [14]. Common government policies in these countries encourage participation in tertiary education. The cornerstone of such policies lies in the belief that a more educated labour force leads to increased economic growth [13]. This situation can be illustrated by the number of students enrolled in tertiary education (both public and private) in the Czech Republic where the enrolment of 19-year olds starting university between 2003 and 2010 increased by more than $20 \%$ [7].

The traditional functions of education, which include teaching students methods and theories and how they are applied in practical life, making students more culturallyaware and providing them with the tools and skills they need to perform qualified work are contradictory to the labour market's needs and basically have an impact in two directions. On the one hand, the expansion of university education is understood as a phenomenon of market growth, and on the other hand, in connection with this issue, we talk more often about overeducation, overqualification or overschooling. This is a situation where graduates have problems finding jobs which correspond to their level of education [12], [15].

There has appeared abundant literature on overqualification in recent decades, both in theoretical and in empirical fields. This issue has also become topical in the Czech Republic. To present the current situation not only in the Czech Republic, but also throughout Europe, researchers use several surveys such as the international survey Reflex, the ESS (European Social Survey), the ISSP (International Social Survey Programme) and the VŠPS (Selected Survey of Labour Force) of PedF UK and its international counterpart, the LFS (Labour Force Survey) [15]. The latest data used for making an analysis of overeducation originate from the PIAAC 2013 survey (Programme for International Assessment of Adult Competencies), collected by the OECD in 24 highly industrialized countries (the results are introduced later in this paper based on an analysis of [18].

After providing a detailed literature overview on the topic of overeducation and job mismatches, the main part of this paper introduces the results both from secondary data published topically on this issue (PIAAC) in 2013 as well as a comparison of previous analyses from ESS surveys.

\section{Overeducation: An Overview of the Literature}

As the average level educational attained by the labour force has risen, there is an indication that the job structure has not been able to absorb this increased supply of educated workers into the traditional occupational rungs, and a state of overeducation has emerged in the labour market [27]. One of the first authors who was concerned with the economic analysis of overqualification from the macroeconomic point of view was Richard B. Freeman in his publication entitled The Overeducated American. In 1976, Freeman found that the rate of return to higher education had fallen in the USA in the 70s and he attributed it to an 
excess supply of graduates [1]. Heckman and Kruger pointed out that the economic value of a bachelor's degree in the 70 s plummeted in the U.S.A. It led Harvard labour economist Richard Freeman to fret over the plight of the "overeducated American" [12].

\subsection{Definitions of Overeducation, Required Education and Undereducation}

The literature used in this paper is focused on educational mismatch and defines key terms as over and under education and over and under qualification. For example, CEDEFOP classifies overeducation as a situation in which an individual has more education than the current job requires (measured in years). On the contrary, undereducation is a situation in which an individual has less education than the current job requires (measured in years) [3]. In this paper, we empirically address overeducation and undereducation. However, some of the literature understands overqualification and overeducation to be synonymous terms. A worker is said to be overeducated if he/she has acquired more education than is required to perform his/her job [21]. Chevalier in [14] presents the results of surveys in extent literature and concludes that empirical work relies on three different definitions of overeducation.

In the first definition, education is compared to their self-assessed qualification required to perform one's job. As many authors (e.g. [9], [16], [20]) point out, this subjective method is also the most popular method used in empirical research and provides reliable internationally comparable data (including ESS and PIAAC, analyzed in the paper below) [17]. Groot and van den Brink [9] call this method as a subjective (self-assessment) method and it can be direct or indirect one: in the direct type, workers are asked directly whether they are overeducated or undereducated for the work they do; in the type of indirect method, workers are asked what the minimum educational requirements are for (a new worker in) the job ([9], p. 150).

Second, an "expert" definition of an educational requirement for a given occupation is used. Expert analyses have been developing mainly in the USA within the traditional O*NET (occupational information network) programme. It provides updated information about hundreds of occupations listed by occupation experts covering approximately $97 \%$ of the occupations on the US labour market [18]. A job analysis conducted by experts brings the best results [9]. However, this data is rarely available and we can find subjective measures in most overeducation analyses [10]. From a metaanalysis of 25 studies of overeducation and overqualification [9, p.153], 50 estimates on the incidence of overqualification and overeducation were obtained and 36 estimates for the incidence of undereducation were obtained. The unweighted average of the incidence of overeducation and overqualification was $23.3 \%$ (with a standard deviation of $9.9 \%$ ) and the unweighted average of the incidence of undereducation and underqualification was $14.4 \%$ (with a standard deviation of $8.2 \%$ ). In a study of the U.K. graduate labour market [4], $38 \%$ of all graduates were overeducated in their first job. This proportion fell to $30 \%$ after six years. The results for the Czech Republic can be found in a study of 25 European countries [8] and are as follows: $49.5 \%$ overeducated; 44.3 undereducated.

Third, the distribution of education is calculated for each occupation; employees who depart from the mean or median by more than some ad hoc value (generally one standard deviation) are classified as overeducated [9].

\subsection{Overeducation, Required Education and Undereducation in the Labour Market}

In connection with labour market mismatch, authors often talk about over or under education. Another aspect related to the mismatch in jobs and graduates is the difference between the field of study of graduates and the actual demand on the labour market (skill mismatch). Most literature is focused on the educational mismatch and only a small portion on skill mismatch. Far less attention is paid to job mismatches referring to the field of education obtained (exceptions are e.g. [25], [30]). There are mainly two reasons for this aspect of jobmismatch. First of all, school-leavers have to compete for the available jobs with those who have already gained a position on the labour market. Their lack of work experience often forces them to face unemployment. Secondly, a relatively large number of school-leavers ends up in jobs that do not match their educational qualifications. These job mismatches can be the result of incomplete information on the abilities 
of school-leavers and the characteristics of jobs offered by employers. In the literature, job mismatches are reported to have serious effects on a number of labour-market outcomes. There has been significant written evidence on the influence of over or undereducation on earnings (mentioned below in part 1.3). In the case of job mismatches with regard to the field of education, Wolbers confirms that there are also wage effects: individuals working in their own field of education earn higher wages than those working outside it [32]. The third possible issue of job-mismatch deals with the imbalance of the use of gained abilities and qualification [25].

Job-matching theory according to Sattinger states that the quality of a job match, i.e. the degree of fit between required and acquired skills, determines the productivity level and earnings in a job. If an employee works in a non-matching job, his/her acquired skills are under-utilized. This imposes a limitation on his/her labour productivity, resulting in lower wages. The allocation of workers is optimal if every worker is matched to a job in which, in relative terms, he/she performs better than all other workers. The incidence of job mismatches, then, is explained by differences in the shares of vacant jobs of a given level and available workers with adequate educational qualifications [23], [31]. Tools to increase conformity between required and offered skills and educational levels in the labour market can help to minimize job mismatch. Countries can influence the quality of provided education, and map the requirements of employers and the expectations of graduates on the labour market.

Wolbers [32], in his cross-national data analysis, concludes that better-educated and occupation-specifically qualified school-leavers are less often employed in a job that does not fit the field of education the students attended in their initial education than lower educated and less occupation-specifically qualified schoolleavers. Moreover, the likelihood of having a job mismatch is also determined by different job characteristics. Job tenure has a negative effect on the likelihood of having a job mismatch. Wolbers also confirms that structural characteristics affect the probability of having a job mismatch. In times of high unemployment, the likelihood of having a job mismatch is higher than in times of low unemployment. When comparing job mismatches between selected
European countries, he found out that almost one-quarter of the variation between countries can be attributed to national differences in the vocational orientation of the education system. There is evidence that countries in which the share of upper secondary education students in school-based vocational education is high, have a higher incidence of job mismatches among school-leavers than countries in which this share is low [32].

There also exists empirical evidence on skill job-mismatch in the Czech labour market between graduates with a secondary degree. The author states that there will be always be some level of job mismatch (both skill and educational) and an imbalance between the supply and demand of workers with a different field of study or achieved degree on the labour market. This can occur due to shortages in the labour market as well as qualitative and quantitative shortages of employees themselves [29]. The requirements of employers can originate from special surveys between employers as well as from data provided by employment agencies about their clients' (employers) requirements. The problem with this method is that it is an inadequate systematic approach for data collection. However this method has recently been given greater importance for searching for a collective approach to connecting data at national levels. For these purposes, researchers can use data from the European Commission (DG Employment) or Eurostat (Survey of continual vocational training - CTVS) [13].

The situation where a university graduate works in a position that requires lower qualifications happens for three reasons. First, it can mean that higher education institutions were not able to provide sufficient abilities and knowledge required from employers to their graduates. Secondly, the reason can arise from a labour market that does not offer enough positions for these university graduates. Thirdly, university graduates may not able to a find matching job position due to labour market imperfections and discrimination [16]. In other words, widening participation in education may lead to an increase in overeducation. Employers faced by a more qualified pool of candidates may have upgraded some traditionally nongraduate jobs. Alternatively, they may recruit graduates for jobs that have basically stayed the same and do not require graduate skills (de 
facto qualification inflation) or since educational standards are commonly suspected to have decreased over-time, upgrade their qualification requirements to select candidates with the appropriate skills (grade-drift) [13].

Van Eijs and Heijke confirm that in cases of a non-optimal match, employers should provide more training to overeducated workers to bring their skills in line with the requirements of the job. This would be the case when the mismatch is minor, i.e. for apparently overeducated workers. Alternatively, human capital theory predicts that overeducated workers are less likely to get training as they compensate their lack of specific skills by an excess of education. Also, overeducated workers might have shorter tenure since they keep looking for a better match, therefore firms are less likely to invest in their training. This type of worker is genuinely overeducated. Hence, apparently overeducated workers receive more employerfunded training than genuinely overeducated workers do. The skill differential generates a difference in the productivity of the different types of graduates. Therefore, the earnings of an overeducated graduate are bound to be lower than those received by matched workers; furthermore it could be anticipated that the genuinely overeducated earn the least [13].

Job assignment theory proposes that even if we accept that the skills obtained in education contribute positively to productivity in general, the extent to which workers can use those skills may depend to some extent on productivity limits imposed by job characteristics. For overeducated workers, job constraints may allow only a limited use of their skills, which in turn limits their productivity and consequently their wages. This would suggest that overeducated workers underutilise their skills and vice versa undereducated workers overutilise their skills. For instance, Dolton and Vignoles, in analysing the early careers 1980 UK graduates, found out that $62 \%$ of male graduates who were overeducated in their first jobs remain in a sub-graduate position six years after graduation [4].

\subsection{Overeducation, Required Education, Undereducation and Earnings}

The incidence and wage effects of overeducation have been well established by empirical studies by e.g. Hartog [10], Sloane [25], McGuinness and Bennett [21] and McGuinness [20]. Previous surveys have generally found that the larger the spread between education obtained and education required, the greater the pay penalty. A well-arranged study on the incidence and wage effects of overeducation was also topically introduced in the publication by [18]. $\mathrm{He}$ refers to two main issues from empirical studies resulting of overeducation effects on earnings. [10], [20], [24], [29].

First, people who work in jobs for which they are overqualified earn less than workers who have the same level of education, but who work in jobs that require that specific level of education. Secondly, overeducated people earn more than people who work in equivalent jobs, but have attained the level of schooling required for that job. This was confirmed by analyses conducted e.g. by [10], [20], [24]. Dolton and Vignoles [4] estimate the pay penalty for overeducated graduates to range between $4 \%$ and $17 \%$. McGuinness [21] estimates an average overeducation penalty for graduates six years after graduation ranging from $11 \%$ to $17 \%$. Many studies dealing with the topic of overeducation conclude that overeducated workers have also lower returns on their education [14].

Empirical analyses consistently show that (1) people who work in jobs for which they are overqualified earn less than workers who have the same level of education, but who work in jobs that require that level of education, and that (2) overeducated people earn more than people who work in equivalent jobs, but have attained the level of schooling required for that job (Sicherman [24], Sloane [25]. Many papers have aimed to explain these stylized facts (Duncan and Hoffman, Hartog and Oosterbeek, Sloane et al. and McGuinness) [18].

\section{Data}

For the aim of this paper two large sets of international data were chosen to show effects of educational mismatch. In the first part of this chapter selected results of PIAAC survey are presented. The second set of data of ESS 5 provides information about effects of educational mismatch on earnings and rates of returns.

\subsection{The OECD's PIAAC Survey}

The recently conducted international largescale PIAAC (International Assessment of Adult 
Competencies) assessment conducted by the OECD provides, besides other issues, reliable measurements of all the elements needed to evaluate the effects of education in connection with overeducation, required education and undereducation, i.e. wages, years of acquired and required schooling and direct measures for key information processing skills. As such, these data allow us to better distinguish between the various theoretical explanations for the relationship between educational mismatches and wages than any previous data set. Although the measured skills are not the perfect measure of all relevant abilities, and much skills heterogeneity will plausibly remain unobserved, these data can be used to establish whether the relationships between wages and overeducation, undereducation and required education can partly be attributed to skills heterogeneity. Furthermore, the cross-national character of the data allows for exploring the role of labour market institutions [18].

Data obtained from the PIAAC are used for more than just the connection with the level of education. The main purpose of this survey was to gain data about human capital in connection with knowledge and skills. The results of this survey are available on a quantitative scale, which enables users to search for and quantify the relationships between different indicators. Data analyzed by Levels at al. [18] contained a total working sample of 26,322 respondents from 21 countries, including the Czech Republic. In order to calculate the results, the authors used the common ORU model explained above. The degree of overeducation is derived from the levels of education reached by the respondents and the education level required for their job. The authors used the operational definition of overeducation that is common in this type of study, and define overeducation as the extent to which individuals have attained an educational level that is higher than is required for the job they have. Selected descriptive statistics of data obtained from the PIAAC (21 countries) is shown in Table 1.

The level of education attained as measured by PIAAC is the nominal number of years

Selected descriptive statistics of data used from PIAAC (21 countries) in 2013

\begin{tabular}{c|c|c|c|c} 
& Minimum & Maximum & Mean & Std. Deviation \\
\hline Monthly wage (US dollars) & 512.9 & $213,198.31$ & $3,490.01$ & $3,497.65$ \\
\hline Required education (years) & 0 & 22 & 12.93 & 3.13 \\
\hline Overeducation (years) & 0 & 18 & 0.89 & 1.78 \\
\hline Undereducation (years) & 0 & 14 & 0.51 & 1.27 \\
\hline Age (years) & 16 & 65 & 40.64 & 11.72 \\
\hline $\begin{array}{c}\text { Work experience (years) } \\
\text { Number of working hours per } \\
\text { week }\end{array}$ & 0 & 55 & 19.87 & 12.18 \\
\hline \begin{tabular}{c} 
(6) \\
\hline
\end{tabular} & 80 & 43.89 & 7.53 \\
\hline
\end{tabular}

respondents spent in formal education. The measure is derived from the reported highest level of education in national education systems, converted into nominal years of schooling by the PIAAC consortium and country experts. Required education in the PIAAC survey is based on the following question: "If applying today, what would be the usual qualifications, if any that someone would need to get this type of job?" According to the results, the measure ranges from 0 to 22 years, with a mean of 12.9 years. Overeducation is derived from what level of education the respondents have attained and the level of education required for their jobs. Undereducation is defined as the extent to which individuals have attained a level of education that is lower than is actually required for the job they have. For the working hour's criteria, the authors use only full-time workers (working more than 36 hours per week). To avoid outliers, the authors used 80 hours as the maximum value. 


\subsection{European Social Surveys}

The ESS2 survey [5] collected data for the years 2004/2005 and according to calculations carried out by authors Lepic and Koucky [17] showed that around $15 \%$ of the respondents on the European labour market are undereducated and approximately $18 \%$ are overeducated. Of those, the highest rate of overeducation has a tertiary education. The distribution of required qualifications for different job positions in Europe currently has two main peaks. There is a surprisingly big share of respondents who believe that their jobs require a minimum of education or training and also a high number of respondents who believe they need between 3-5 years of education or professional training [17].

In the ESS2 and ESS5 surveys, the respondents were questioned about the qualification requirements and characteristics of their job descriptions. In parts $F$ and $G$ of these questionnaires, they were to answer questions that indicate the quantification of overeducation using this first method that was introduced above, i,e. the subjective method.

The ESS5 survey [6] collected data for the years 2010/2011 and was conducted in 26 countries and the overall number of respondents was 52,458. For our analysis, data from 21 EU countries were used (no relevant data were available for Austria, Italy,
Latvia, Luxembourg, Malta or Romania) and the number of respondents was reduced to 11,137 ; the self-employed and respondents who did not perform any economic activity, such as pensioners, students etc., were omitted. All country samples include only persons aged 15 and over, regardless of their nationality, citizenship or language. Individuals were selected by strict random probability methods by ESS5 researchers.

\section{Methodology}

For calculation the educational mismatch impact we use data collected by using a subjective indirect method. For the further analysis modified Mincer's earnings equation and OLS (ordinary least squares) regression were used. Results are provided in the following subchapter.

\subsection{Educational Mismatch Incidence}

For our paper, first we calculated basic educational statistics of our sample $(11,137$ respondents, 21 EU countries): means of years of education; means of age; means of experience and means of salary (all of them separately for males and females). A summary of descriptive statistics of our sample is presented in Table 2.

\begin{tabular}{c|c|c} 
Tab. 2: & \multicolumn{3}{c}{ Descriptive statistics for selected EU countries - means of relevant variables; } \\
standard deviations in parentheses & Male & Female \\
\hline S (years of education) & $12.53(2.430)$ & $12.86(2.431)$ \\
\hline Age (years) & $41.69(11.874)$ & $42.18(11.445)$ \\
\hline Experience (years) & $20.77(12.258)$ & $19.52(11.610)$ \\
\hline Monthly salary (EUR) & $2,300.26(1,997.98)$ & $1,635.77(1,426.96)$ \\
\hline
\end{tabular}

Source: [6], own calculations

A proportion of adequately educated, overeducated and undereducated workers in our sample was calculated using subjective indirect method, as mentioned in the part 1.1 of the paper. Questions from the ESS5 survey (ESS5, 2010) focusing on data required for evaluating overeducation and undereducation were: F34a: "What training or qualifications are/ were needed for the job?", G23: "If someone were applying today for the job you currently have, would they need any education or vocational schooling beyond a compulsory education?", G24: "About how many years of education or vocational schooling beyond a compulsory education would they need?" These data provide possibility to evaluate the level of education obtained by the respondents and also required for given jobs and thus to calculate extent of overeducation or undereducation of the respondents. 


\subsection{Educational Mismatch and Earnings}

As Levels at al. [18] and many other authors (e.g. [8], [21] etc.) point out, a significant expansion of the classic Mincerian wage function proposed by Duncan and Hoffman enables researchers to use a model that evaluates earnings connected with individuals' attained levels of education and the levels of education required in their job. This model is also known as the ORU model (where $O$ stands for Overqualification, $R$ for Required and $U$ for Underqualification). The ORU model is very often used to calculate the effects of over or undereducation on wages.

Using the ORU model, Levels et al. [18] found out that the relationship between the required number of years of schooling and wages is positive. The strength of the relationship indicates that each additional year of required schooling yields a wage premium of approximately $8 \%$. The effect of overeducation is less than half that amount, with an estimated $3.3 \%$. This means that each additional year of education yields a wage premium of approximately $3 \%$. Undereducation is negatively related to wages and each year of undereducation yields a wage penalty of around $2 \%$.

Levels at al. expanded the basic formula of the ORU model to indicate also the influence of numeracy skills on wages. Using the modified equation, they determined that there is indeed a considerable cross-national variation in the effect of numeracy skills on wages, ranging from a low of 0.052 in the Czech Republic to a high of 0.237 in the United Kingdom. They also found out that in the Czech Republic, skills contribute much less to the explanation of the relationship between required education and wages (only $6 \%$ ) compared to the UK, where skills are an important factor used to explain the returns on required education (23\%). In addition, for the returns to overeducation in the Czech Republic, barely any of this effect is explained by skills $(8 \%)$, whereas in the US and Japan, it is more than $60 \%$. The proportion of the wage effect of undereducation that is explained by skills in the Czech Republic is also very low (14\%), which is contrary to Denmark (93\%) and Japan (51\%).

The findings of the Levels et al. survey from the PIAAC data (from 2013) confirmed results that are in line with earlier studies. They showed that overeducated workers earn less than workers who have the same level of education, but work in jobs that require their level of education, and overeducated workers earn more than people who work in equivalent jobs, but have attained the level of schooling required for that job. They also proved that skills heterogeneity considerably contributes to the explanation of educational mismatch. The effect of numeracy skills on wages explains approximately one-sixth of the wage effect of required education, and little under onethird of the wage effects of overeducation and undereducation. They concluded that skills do matter when explaining the wage effects of education and educational mismatches, but that the extent to which this is the case also depends on institutional contexts [18].

We estimated the effects of overqualification and of underqualification on earnings (i.e. on returns to adequate schooling, over- and underschooling) using a modified Mincer's earnings equation based on Cohn [2] and converted to the following equation:

$\ln w_{i}=X_{i} \beta+\alpha_{1} A D S C H_{i}+\alpha_{2} \mathrm{OVERSCH}_{i}+\alpha_{3} U N D E R S C H$ $+\alpha_{4} A G E_{i}+\alpha_{5} G E N_{i}+\alpha_{6} E X P+\alpha_{7} E X P^{2}+u$

where $\mathbf{l n} \mathbf{w}_{\mathbf{i}}$ is the natural logarithm of gross earnings, $\alpha$ are regression coefficients, $\mathrm{ADSCH}_{i}$ is the number of years of adequate schooling, OVERSCH and UNDERSCH are numbers of years of over-schooling and underschooling (OVERSCH $=$ SCHOOL - ADSCH, where SCHOOL is the number of years of actual education; similarly UNDERSCH = ADSCH - SCHOOL), EXP are years of experience, GEN is a dummy variable for the gender of the respondent, $\mathbf{X}_{i}$ is a set of other variables assumed to affect earnings and $\mathbf{u}_{i}$ is a disturbance term (index $\mathrm{i}$ is for individual $\mathrm{i}$ ).

\section{Results}

The results of our calculations of educational mismatch incidence obtained by the subjective method and using data from ESS5 sample are in Table 3 and Table 4.

Results of our calculations of the OLS regression analysis using model (1) are in Table 5 and Table 6. Data from ESS5 was used for calculating natural logarithm of monthly wage in Euros as a dependent variable; independent variables were required education (Column Adeq. in Table 6), Overeducation (Column Over in Table 6) and Undereducation (Column Under in Table 6), age and gender of the respondent, working experience and experience square. 
Percentage distribution of adequate qualification, under- and overeducation, 21 EU countries

\begin{tabular}{c|c|c|c} 
& All & Male & Female \\
\hline Undereducated & 29.34 & 32.40 & 26.43 \\
\hline Adequately educated & 22.43 & 21.36 & 23.42 \\
\hline Overeducated & $\mathbf{4 8 . 2 4}$ & $\mathbf{4 6 . 2 4}$ & $\mathbf{5 0 . 1 4}$ \\
\hline
\end{tabular}

Source: [6], own calculations

\begin{tabular}{|c|c|c|c|c|c|c|c|}
\hline \multirow[t]{2}{*}{ Tab. 4: } & \multicolumn{7}{|c|}{$\begin{array}{l}\text { Means of over-schooling, under-schooling, adequate schooling, education, age, } \\
\text { years of experience, } 21 \text { EU countries }\end{array}$} \\
\hline & & $\begin{array}{l}\text { Years of over } \\
\text { schooling }\end{array}$ & $\begin{array}{c}\text { Years of } \\
\text { under } \\
\text { schooling }\end{array}$ & $\begin{array}{c}\text { Years of } \\
\text { education } \\
\text { necessary for } \\
\text { job }\end{array}$ & $\begin{array}{l}\text { Years of } \\
\text { full-time } \\
\text { education }\end{array}$ & $\begin{array}{c}\text { Age of } \\
\text { respondent }\end{array}$ & $\begin{array}{l}\text { Years of } \\
\text { experience }\end{array}$ \\
\hline $\begin{array}{c}\text { All } \\
\mathrm{N}=11,137\end{array}$ & $\begin{array}{c}\text { Mean (Std. } \\
\text { deviation) }\end{array}$ & $\begin{array}{c}2.86 \\
(1.63)\end{array}$ & $\begin{array}{c}1.95 \\
(1.29)\end{array}$ & $\begin{array}{l}12.51 \\
(2.58) \\
\end{array}$ & $\begin{array}{l}12.70 \\
(2.44) \\
\end{array}$ & $\begin{array}{c}41.94 \\
(11.66)\end{array}$ & $\begin{array}{c}20.12 \\
(11.94) \\
\end{array}$ \\
\hline $\begin{array}{l}\text { Males } \\
\mathrm{N}=5,393\end{array}$ & $\begin{array}{l}\text { Mean (Std. } \\
\text { deviation) }\end{array}$ & $\begin{array}{c}2.79 \\
(1.58)\end{array}$ & $\begin{array}{c}1.98 \\
(1.38)\end{array}$ & $\begin{array}{l}12.44 \\
(2.61)\end{array}$ & $\begin{array}{l}12.53 \\
(2.43)\end{array}$ & $\begin{array}{c}41.69 \\
(11.87)\end{array}$ & $\begin{array}{c}20.77 \\
(12.26)\end{array}$ \\
\hline $\begin{array}{l}\text { Females } \\
N=5,744\end{array}$ & $\begin{array}{c}\text { Mean (Std. } \\
\text { deviation) }\end{array}$ & $\begin{array}{c}2.93 \\
(1.66)\end{array}$ & $\begin{array}{c}1.92 \\
(1.18)\end{array}$ & $\begin{array}{l}12.58 \\
(2.55)\end{array}$ & $\begin{array}{l}12.86 \\
(2.53)\end{array}$ & $\begin{array}{c}42.18 \\
(11.44)\end{array}$ & $\begin{array}{c}19.52 \\
(11.61)\end{array}$ \\
\hline
\end{tabular}

Source: [6], own calculations

Tab. 5: Summary of regressions for $21 \mathrm{EU}$ countries - dependent variable InW

\begin{tabular}{c|c|c|c|c|c|c}
\multicolumn{2}{c|}{ Model } & R & R-squared & \multicolumn{2}{c|}{$\begin{array}{c}\text { Adjusted } \\
\text { R-squared }\end{array}$} & \multicolumn{2}{c}{$\begin{array}{c}\text { Std. Error } \\
\text { of the Estimate }\end{array}$} \\
\hline \multirow{2}{*}{} & 1 & $.364^{a}$ & .132 & .132 & \multicolumn{2}{|c}{.83224} \\
\hline \multicolumn{2}{c|}{ Model } & $\begin{array}{c}\text { Sum of } \\
\text { Squares }\end{array}$ & df & Mean Square & F & Sig. \\
\hline \multirow{3}{*}{1} & Regression & 783.389 & 7 & 111.913 & 161.579 & $.000^{a}$ \\
\cline { 2 - 8 } & Residual & $5,136.471$ & 7,416 & .693 & & \\
\cline { 2 - 8 } & Total & $5,919.861$ & 7,423 & & & \\
\hline
\end{tabular}

a. Predictors: (Constant), Experience square, Years necessary for job calculated for full time education (ADSCH), Gender, OVERSCH, UNDERSCH, Age of respondent, Total number of years in full-or part time work (EXP).

Source: [6], own calculations of OLS regression

The results of OLS regression of model (1) in the Table 5 show that our model explains about $13 \%$ of variation in $\operatorname{lnW}$ for all selected countries together. The R-Squared and Adjusted R-Squared statistics are very close in magnitude since there are a large number of degrees of freedom ( $\mathrm{df}=7,416$ for residual sum of squares).
In the Table 7, there are results of OLS regression of model (1) when we split our data to 21 individual countries blocks; explained part of InW variation by our model is higher (between 13.8\% for the Czech Republic and $55.1 \%$ for Portugal).

Using the model (1), we calculated returns on education from our data for individual EU 
Tab. 6:

Returns on adequate education, overeducation and undereducation in $21 \mathrm{EU}$ countries together

\begin{tabular}{l|c|c|c|c}
\multirow{2}{*}{$\begin{array}{l}\text { Selected EU countries (21 count- } \\
\text { ries, 11,137 respondents) }\end{array}$} & \multicolumn{2}{|c|}{ Unstandardized Coefficients } & \multirow{2}{*}{$\mathbf{t}$} & \multirow{2}{*}{ Sig. } \\
\cline { 2 - 5 } & $\mathbf{B}$ & Std. Error & & \\
\hline Adequate schooling & .126 & .005 & 26.811 & .000 \\
\hline OVERSCH & .091 & .006 & 14.418 & .000 \\
\hline UNDERSCH & -.066 & .010 & -6.505 & .000 \\
\hline
\end{tabular}

Source: [6], own calculations

\section{Tab. 7: Summary of regressions for $21 \mathrm{EU}$ countries - dependent variable InW}

\begin{tabular}{l|c|c|c|c}
\multicolumn{1}{c|}{ Country } & $\mathbf{R}$ & R-Squared & $\begin{array}{c}\text { Adjusted } \\
\text { R-Squared }\end{array}$ & $\begin{array}{c}\text { Std. Error of the } \\
\text { Estimate }\end{array}$ \\
\hline Belgium & .657 & .432 & .420 & .35453 \\
\hline Bulgaria & .515 & .265 & .250 & .38904 \\
\hline Cyprus & .618 & .383 & .344 & .38838 \\
\hline Czech Republic & .394 & .155 & .138 & .47571 \\
\hline Germany & .627 & .393 & .386 & .53579 \\
\hline Denmark & .552 & .305 & .296 & .39958 \\
\hline Estonia & .613 & .376 & .362 & .51654 \\
\hline Spain & .597 & .356 & .338 & .45844 \\
\hline Finland & .591 & .349 & .341 & .36167 \\
\hline France & .659 & .434 & .425 & .35580 \\
\hline United Kingdom & .567 & .322 & .310 & .61694 \\
\hline Greece & .415 & .172 & .145 & .49462 \\
\hline Hungary & .564 & .318 & .303 & .40853 \\
\hline Ireland & .592 & .350 & .335 & .55194 \\
\hline Lithuania & .451 & .203 & .176 & .50579 \\
\hline Netherlands & .673 & .453 & .444 & .37416 \\
\hline Poland & .569 & .323 & .310 & .46212 \\
\hline Portugal & .768 & .591 & .551 & .32021 \\
\hline Sweden & .610 & .372 & .364 & .30187 \\
\hline Slovenia & .695 & .483 & .469 & .38281 \\
\hline Slovakia & .593 & .352 & .336 & .31678 \\
\hline
\end{tabular}

Source: [6], own calculations

countries; results of OLS regression are in Table 8. It shows that returns of adequate education are between $7.7 \%$ (Bulgaria) and $17.5 \%$ (Slovenia). These results are comparable with the results from the meta-analysis by Groot and van den Brink [9], where there were analysed 25 studies of overeducation and undereducation in the labour market. From these 25 studies, they obtained unweighted average rates of the return to the different educational component: $7.8 \%$ for years of education required for the job, 3.0\% for years of overeducation and $-1.5 \%$ for years of undereducation ([9], p. 153). It should be noted that in the above mentioned meta-analysis 


\begin{tabular}{|c|c|c|c|c|c|c|c|c|c|c|c|c|}
\hline Tab. 8: & tu & & 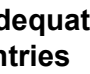 & & & & & & & & & \\
\hline Coun & Adeq. & $\begin{array}{l}\text { Std. } \\
\text { error }\end{array}$ & $t$ & Sig. & Over & $\begin{array}{l}\text { Std. } \\
\text { error }\end{array}$ & $t$ & Sig. & Under & $\begin{array}{l}\text { Std. } \\
\text { error }\end{array}$ & $t$ & Sig. \\
\hline Belgium & .129 & .011 & 11.584 & .000 & .105 & .013 & 8.141 & .000 & .083 & .030 & -2.791 & .006 \\
\hline Bulgal & 077 & .010 & 8.048 & .000 & .06 & .018 & .594 & .000 & .039 & .029 & 1.351 & .178 \\
\hline Cyprus & .106 & 020 & 5.230 & .000 & .093 & .022 & 4.190 & .000 & -.115 & .026 & 4.500 & .000 \\
\hline $\begin{array}{l}\text { Czech } \\
\text { Republic }\end{array}$ & .101 & .015 & 6.535 & .000 & .075 & .021 & 3.643 & .000 & -.079 & .036 & -2.199 & .029 \\
\hline Denmark & .092 & 008 & 1.003 & .000 & .027 & .017 & 1.543 & .123 & -.051 & .014 & -3.674 & .000 \\
\hline Estonia & .155 & .017 & 9.311 & .000 & .106 & .016 & 6.592 & .000 & -.087 & .063 & -1.387 & .166 \\
\hline Finland & .092 & .008 & 11.484 & .000 & .068 & .014 & 4.775 & .000 &. .028 & .017 & -1.653 & .099 \\
\hline France & .109 & .007 & 14.587 & .000 & .065 & .012 & 332 & .000 & -.098 & .015 & 677 & .000 \\
\hline Germany & .159 & .013 & 12.341 & .000 & .071 & .016 & 4.493 & .000 & -129 & .024 & -5.357 & .000 \\
\hline Greece & .080 & .016 & 4.901 & .000 & .063 & .019 & 3.307 & .001 & -.072 & .040 & -1.808 & .072 \\
\hline Hungary & .140 & .012 & 11.539 & .000 & .104 & .023 & 22 & .000 & 133 & .026 & 168 & .000 \\
\hline Ireland & .170 & .017 & 9.878 & .000 & .055 & .019 & 2.842 & .005 & -.163 & .033 & -5.011 & .000 \\
\hline Lithuania & .131 & .020 & 6.633 & .000 & .069 & .018 & 3.845 & .000 &. .097 & .096 & -1.007 & .315 \\
\hline Nether & .131 & .010 & 13.625 & .000 & .055 & .012 & $4.5<0$ & .000 & -.079 & .019 & -4.201 & .000 \\
\hline Poland & .113 & .010 & 10.870 & .000 & .095 & .015 & 6.245 & .000 & .038 & .024 & -1.632 & .104 \\
\hline Portugal & .118 & .015 & 7.945 & .000 & .043 & .024 & 1.763 & .082 & -158 & .039 & -4.069 & .000 \\
\hline Slovakia & .096 & .009 & 10.450 & .000 & .085 & .012 & 6.874 & .000 & .001 & .022 &. .042 & .967 \\
\hline Slovenia & .175 & .015 & 11.837 & .000 & .150 & .048 & 3.104 & .002 & -.067 & .026 & -2.606 & .010 \\
\hline Spain & .094 & .012 & 7.836 & .000 & .051 & .018 & 2.796 & .006 & -.084 & .033 & -2.553 & .011 \\
\hline Sweden & .088 & .007 & 12.414 & .000 & .060 & .010 & 5.803 & .000 & -.026 & .014 & $\underline{-1.795}$ & .073 \\
\hline $\begin{array}{l}\text { United } \\
\text { Kingdom }\end{array}$ & 161 & .017 & 9.632 & .000 & .065 & .019 & 3.527 & .000 & 034 & .036 & $\underline{-.956}$ & .340 \\
\hline
\end{tabular}

Results not significant at $5 \%$ level are in bold underlined italics.

\section{Tab. 9: \\ Returns on adequate education, overeducation and undereducation in $21 \mathrm{EU}$ countries together}

\begin{tabular}{l|c|c|c|c}
\multirow{2}{*}{$\begin{array}{c}\text { Selected EU countries } \\
(\mathbf{2 1} \text { countries, } \\
\mathbf{1 1 , 1 3 7} \text { respondents) }\end{array}$} & \multicolumn{2}{|c|}{ Unstandardized Coefficients } & \multirow{2}{*}{ Sig. } \\
\cline { 2 - 3 } & $\mathbf{B}$ & Std. Error & & \\
\hline Adequate schooling & .126 & .005 & 26.811 & .000 \\
\hline OVERSCH & .091 & .006 & 14.418 & .000 \\
\hline UNDERSCH & -.066 & .010 & -6.505 & .000 \\
\hline
\end{tabular}

Source: [6], own calculations 
were used studies with all types of educational mismatch definitions; the results in the Table 8 are similar to these studies in the meta-analysis where subjective definition was used.

Similarly, calculated rates of return on overeducation are between $2.7 \%$ (Denmark this result is not significant at the $5 \%$ level) and $15 \%$ (Slovenia). Returns on undereducation are all negative, between $-0.1 \%$ for Slovakia (not significant at the $5 \%$ level) and $-16.3 \%$ for Ireland.
For all countries together, rates of return to required education, overeducation and undereducation are presented in the Table 9; the calculated results are also comparable with those in the meta analysis by Groot and van den Brink [9] and in the analysis of overeducation in the UK carried out by Dolton and Vignoles [4].

The differences between rates of return to different are presented in Figure 1 below.

The results presented above in Table 8 show that overeducation is a very important

\section{Fig. 1: Returns on Education in 21 European Countries, ESS5}

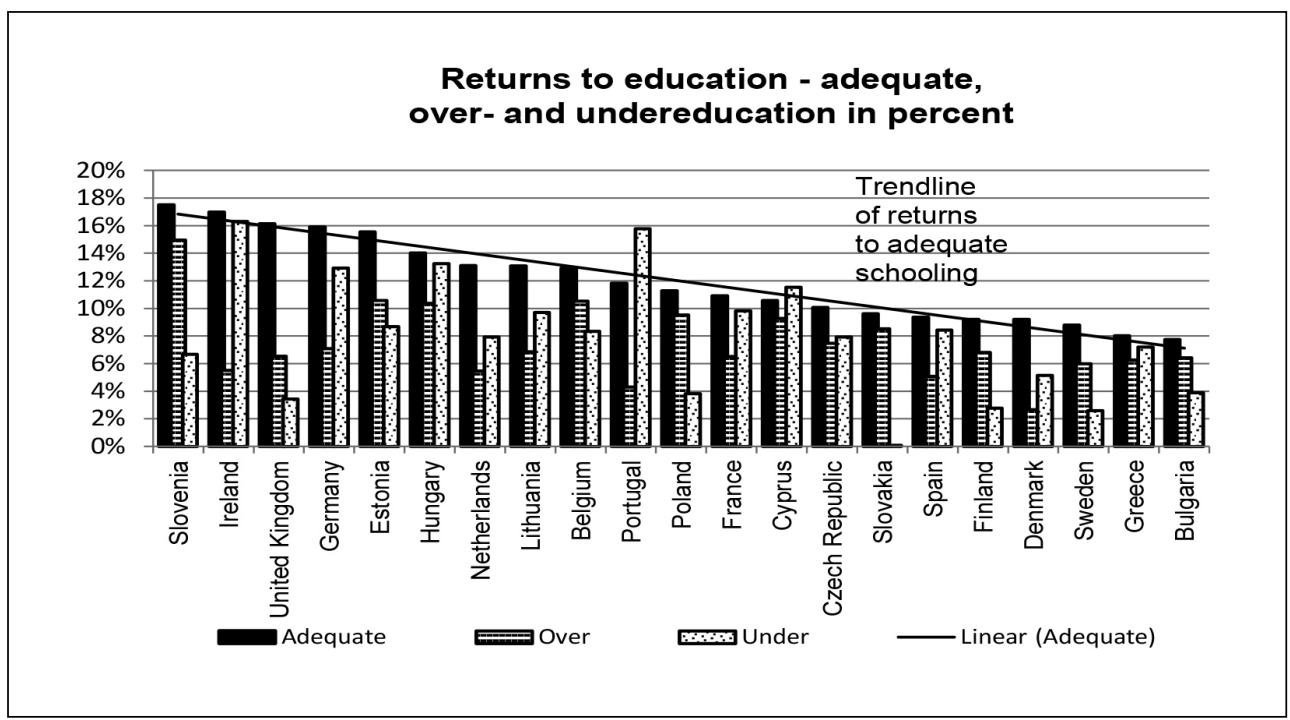

Source: [6], own calculations

issue in all developed countries and it is a great challenge to the relevance of more investment in education. If many workers have more than the required amount of education or qualifications, then continuing to expand secondary and higher education is inefficient. Research carried out in this part of the paper addressed questions connected with education and earnings and with returns on investment in education based on the theory of human capital.

Concerning the effect of schooling on earnings in Model 1 of Table 4, we obtain high rates of return to adequate schooling, lower but positive rates of return to overschooling, and negative rates of return to underschooling. Although our analysis is based on excellent data from European Social Survey Round 5 [6] we recognize that our findings are limited by several issues of a theoretical and methodological nature. First, in our model specification we assumed that the workers in our sample are a homogenous group differentiated only by their age, gender and education attainment, without taking into account their different skill, personal abilities and other traits influencing their earnings. Next, we did not consider the issue of empirical bias associated with various 
definitions and measures of overeducation and undereducation and we assumed that these various approaches to this question create broadly similar results [20]. Thirdly, from the theoretical point of view, we used the modified Mincer's equation based on decomposition of acquired educational years to years of required education, years of overeducation and undereducation [2]. We assume that such decomposition is consistent with original human capital theory and that it helps to explain overeducation and undereducation differences in earnings taking into account such circumstances as e.g. differences in informal human capital and skill of workers, their different abilities acquired in on-the-job training and also other overeducation and undereducation considered as a temporary phenomenon.

\section{Conclusions}

Today, many developed countries have to face problems with educational and skills mismatches. Background literature in the past proved the importance of investment into education both for individuals and society. This paper focuses only on educational mismatches, however compared to other authors; it differentiates between the terms educational and qualification mismatch. Comparing all data introduced in this paper, we have identified different results in the educational mismatch both in international and Czech data. The PIAAC data presented by Levels et al. show a relatively high proportion in educational matches [18]. In addition, as mentioned above, Groot and Van der Brink [9] estimate the average overeducation rate as measured by the self-reporting method to be $28.6 \%$ and the undereducation rate to be $15.5 \%$. However, other studies confirm a higher amount of those who are overeducated. The same proportion was confirmed by our data presented in the ESS5 survey and its analysis.

For policy decisions should be also carried out examination of wage distribution in individual levels of education (basic, secondary, tertiary), also returns to education in specific fields of study and returns to specific skills and other types of working qualifications.

Even though the current situation in educational policies supports an increasing number of university graduates, both the graduates and employers have to face a misbalance on the labour market and lower individual satisfaction. The data presented in this paper open a space for further discussion. They proved that educational mismatches have become a serious issue which needs to be solved not only by politicians, but also by the complexity of the entire system of public and private higher education.

\section{References}

[1] BRYNIN, M. and LONGHI, S. Overqualification: Major or minor mismatch? Economics of Education Review. 2009, Vol. 28, Iss. 1, pp. 114-121. ISSN 0272-7757. DOI: 10.1016/j.econedurev.2008.01.003.

[2] COHN, E. and YING CHU NG. Incidence and wage effects of overeschooling and underschooling in Hong Kong. Economics of Education Review. 2000, Vol. 19, Iss. 2, pp. 159-168. ISSN 0272-7757.

[3] CEDEFOP. The skill matching challenge: Analysing skill mismatch and policy implications. Luxembourg: Publications Office of the European Union, 2010. 93 p. ISBN 97892-896-0485-7.

[4] DOLTON, P., VIGNOLES, A. The incidence and effects of overeducation in the U.K. graduate labour market. Economics of Education Review. 2000, Vol. 19, Iss. 2, pp. 179-198. ISSN 0272-7757.

[5] European Social Survey Round 2 (ESS2) [online]. Norwegian Social Science Data Service [cit. 2012-12-11]. Available from: http:// ess.nsd.uib.no/ess/round2/.

[6] European Social Survey Round 5 (ESS5) [online]. Norwegian Social Science Data Service [cit. 2013-1-16]. Available from: http:// ess.nsd.uib.no/ess/round5/.

[7] FINARDI, S., MAZOUCH, P., FISCHER, J. Odhad míry návratnosti investic do vysokoškolského vzdělání podle oborů, pohlaví a regionů. Politická ekonomie. 2012, Vol. 60, Iss. 5, pp. 563-589. ISSN 0032-3233. DOI: $10.18267 /$ j.polek.864.

[8] GALASI, P. The effect of educational mismatch on wages for 25 countries [online]. Budapest: Institute of Economics, Hungarian Academy of Sciences, 2008 [cit. 2012-01-16]. 24 p. (PDF). Available from: http://econ.core.hu/ file/download/bwp/BWP0808.pdf.

[9] GROOT, W. and BRINK van den, $H$. Overeducation in the labour market: a metaanalysis. Economics of Education Review. 2000 , Vol. 19, Iss. 2, pp. 149-158. ISSN 0272- 
7757. DOI: 10.1111/j.0950-0804.2006.00284.x. [10] HARTOG, J. Overeducation and earnings: where are we, where should we go? Economics of Education Review. 2000, Vol. 19, Iss. 2, pp. 131-147. ISSN 0272-7757. DOI: 10.1016/ S0272-7757(99)00050-3.

[11] HARTOG, J., WOLTER, S.C., SCHWERI, J. Do students expect compensation for wage risk? Economics of Education Review. 2011, Vol. 30, Iss. 2, pp. 215-227. ISSN 0272-7757. DOI: 10.1016/j.econedurev.2010.12.001.

[12] HECKMAN, J.J., KRUEGER, A.B. Inequality in America: What Role for Human Capital Policies? Education Next [online]. 2005, Vol. 4, No. 2 [cit. 5.11.2013]. Available from: http://educationnext.org/school-reformeconomics. ISSN 1539-9664.

[13] HORÁKOVÁ, M. Význam konceptu lidského kapitálu $v$ ekonomické teorii $v$ době ekonomické recese. Fórum sociální politiky. 2010, Vol. 4, Iss. 6, pp. 8-16. ISSN 1802-5854. [14] CHEVALIER, A. Graduate Over-Education in the UK. Centre for the Economics of Education [online]. London: CEE, 2000 [cit. 2013-11-05]. 27 p. (PDF). Available from: http://cee.Ise.ac.uk/ ceedps/ceedp07.pdf. ISSN 2045-6557.

[15] KOUCKÝ, J. and ZELENKA, M. Uplatnění absolventů vysokých škol na trhu práce [online]. Praha: Středisko vzdělávací politiky, Univerzita Karlova v Praze, 2009 [cit. 201311-11]. 38 p. (PDF). Available from: http:// www.strediskovzdelavacipolitiky.info/download/ Absolventi\%20Expertiza\%200ct09.pdf.

[16] KOUCKÝ, J. and ZELENKA, M. Postavení vysokoškoláků a uplatnění absolventů vysokých škol na pracovním trhu 2011 [online]. Praha: Středisko vzdělávací politiky, Univerzita Karlova v Praze, 2011 [cit. 2013-1111]. 33 p. (PDF). Available from: http://www. strediskovzdelavacipolitiky.info/download/ Absolventi_V\%C5\%A0_2011.pdf.

[17] LEPIČ, M. and KOUCKÝ, J. Kvalifikační potřeby trhu práce [online]. Praha: Národní ústav pro vzdělávání, 2012 [cit. 2013-11-11]. 90 p. (PDF). Available from: http://www.nuv. cz/uploads/Vzdelavani_a_TP/Uplatneni_ absolventu_za_rok_2012_internet_final.pdf.

[18] LEVELS, M., VELDEN, R.K.W. and ALLEN, J.P. Educational mismatches and skills: New empirical tests of old hypotheses [online]. Maastricht: Research Centre for Education and the Labour Market. Maastricht University, 2013 [cit. 2014-03-20]. 41 p. (PDF). Available from: http://www.roa.unimaas.nl/pdf_
publications/2013/ROA_RM_2013_18.pdf.

[19] MAZOUCH, P. and FISCHER, J. Lidský kapitál - měření, souvislosti, prognózy. Praha: C.H. Beck, 2011. ISBN 978-80-7400-380-6.

[20] McGUINNESS, S. Overeducation in the Labour Market. Journal of Economic Surveys. 2006, Vol. 20, Iss. 3, pp. 387-418. ISSN 14676419. DOI: 10.1111/j.0950-0804.2006.00284.x.

[21] McGUINESS, S., BENNETT, J. Overeducation in the graduate market: A quantile regression approach. Economics of Education Review. 2007, Vol. 26, Iss. 5, pp. 521-531. ISSN 0272-7757. DOI: 10.1016/j. econedurev.2005.12.003.

[22] METHA, A., et al. Overeducation in developing economies: How can we test for it, and what does it mean? Economics of Education Review. 2011, Vol. 30, Iss. 6, pp. 1334-1347. ISSN 0272-7757. DOI: 10.1016/j. econedurev.2011.06.004.

[23] SATTINGER, M. Assignment Models of the Distribution of Earnings. Journal of Economic Literature. 1993, Vol. 31, No. 2, pp. 831-880. ISSN 0022-0515.

[24] SICHERMAN, N. "Overeducation" in the Labor Market. Journal of Labor Economics. 1991, Vol. 9, No. 2, pp. 101-122. ISSN 0734306X.

[25] SLOANE, P.J. Much ado about Nothing? What does the Overeducation Literature Really Tell us? In: BÜCHEL, F., GRIP, de A., MERTENS, A. (Eds.). Overeducation in Europe. Cheltenham: Edward Elgar, 2004. pp. 11-45. ISBN 1-84376-361-3.

[26] SOLGA, H., KONIETZKA, D. Occupational matching and social stratiffcation: theoretical insights and empirical observations taken from a German-German comparison. European Sociological Review. 1999, Vol. 15, Iss. 1, pp. 25-47. ISSN 0266-7215.

[27] TSAI, Y. Returns to Overeducation: A Longitudinal Analysis of the U.S. Labour Market. Economics of Education Review. 2010, Vol. 29, Iss. 4, pp. 606-617. ISSN 0272-7757. DOI: 10.1016/j.econedurev.2010.01.001.

[28] TSANG, M.C., LEVIN, M.H. The economics of overeducation. Economics of Education Review. 1985, Vol. 4, Iss. 2, pp. 93-104. ISSN 0272-7757. DOI: 10.1016/02727757(85)90051-2.

[29] URBÁNEK, V. Returns on Education and Overqualification - Case of the EU and the Czech Republic. ACC Journal. 2013, Vol. 19, Iss. 2, pp. 178-190. ISSN 1803-9782. 
[30] WALKER, I., ZHU, Y. Differences by degree: Evidence of the net financial rates of return to undergraduate study for England and Wales. Economics of Education Review. 2011, Vol. 30, Iss. 6, pp.1177-1186. ISSN 0272-7757. DOI: 10.1016/j.econedurev.2011.01.002.

[31] WITTE, J., KALLEBERG, A. Matching Training and Jobs: the Fit between Vocational Education and Employment in the German Labour Market. European Sociological Review. 1995, Vol. 11, Iss. 3, pp. 293-317. ISSN 0266-7215.

[32] WOLBERS, M.H.J. Job Mismatches and their Labour-Market Effects among SchoolLeavers in Europe. European Sociological Review. 2003, Vol. 19, Iss. 3, pp. 249-266. ISSN 0266-7215. DOI: 10.1093/esr/19.3.249. doi: 10.1093/esr/19.3.249.
Ing. Kateřina Maršíková, Ph.D.

Technical University of Liberec

Faculty of Economics

Department of Business Administration and Management katerina.marsikova@tul.cz

doc. Ing. Václav Urbánek, CSc. Technical University of Liberec

Faculty of Economics

Department of Business Administration and Management vaclav.urbanek@tul.cz 


\section{Abstract}

\section{A COMPARISON OF EDUCATIONAL MISMATCHES ACROSS EUROPE}

\section{Kateřina Maršíková, Václav Urbánek}

Research undertaken during the last few years illustrates a major mismatch between educational systems worldwide and occupations in the labour market. The literature focuses both on educational and job mismatches however the aim of this paper is to compare only the situation concerning educational mismatches. For the aim of this paper, two large sets of international data were chosen to show effects of educational mismatch. In the first part, selected results of PIAAC survey are presented. In the analytical part, data from European Social Survey ESS5 collected in the years 2010 and 2011 in selected EU countries were used. The first part of the paper provides a literature background presented so far (e.g. Dolton, Galasi, Hartog, Chevalier, Levels, and McGuinness etc.) as well as methods used to identify this mismatch both by employers and employees. The European Social Survey data were used for modified Mincer's earnings equation in the second part of the paper and regression estimates proved that overeducation is a very important issue in all developed countries. The results also introduce data on returns on investment in education based on the human capital theory which helps to explain overeducation and undereducation differences in earnings taking into account different circumstances as e.g. variation in informal human capital and skill of workers, their abilities acquired in on-the-job training and also other overeducation and undereducation considered as a temporary phenomenon. It is a great challenge to the relevance of more investment in education. Even though the current situation in educational policies supports an increasing number of university graduates, both the graduates and employers have to face a misbalance on the labour market and lower individual satisfaction. The results confirm the findings of some of previous studies and offer a platform for further discussion of educational mismatch across Europe. PIAAC.

Key Words: Overeducation, educational mismatch, rate of return, European Social Survey,

JEL Classification: J21, J24, J31.

DOI: 10.15240/tul/001/2015-4-002 